IZADP No. 1549

The Changing Wage Return to an Undergraduate Education

Nigel C. O'Leary

Peter J . Sloane

March 2005 


\title{
The Changing Wage Return to an Undergraduate Education
}

\author{
Nigel C. O'Leary \\ WELMERC, University of Wales Swansea \\ Peter J. Sloane \\ WELMERC, University of Wales Swansea \\ and IZA Bonn
}

Discussion Paper No. 1549

March 2005

\author{
IZA \\ P.O. Box 7240 \\ 53072 Bonn \\ Germany \\ Phone: +49-228-3894-0 \\ Fax: +49-228-3894-180 \\ Email: iza@iza.org
}

\begin{abstract}
Any opinions expressed here are those of the author(s) and not those of the institute. Research disseminated by IZA may include views on policy, but the institute itself takes no institutional policy positions.

The Institute for the Study of Labor (IZA) in Bonn is a local and virtual international research center and a place of communication between science, politics and business. IZA is an independent nonprofit company supported by Deutsche Post World Net. The center is associated with the University of Bonn and offers a stimulating research environment through its research networks, research support, and visitors and doctoral programs. IZA engages in (i) original and internationally competitive research in all fields of labor economics, (ii) development of policy concepts, and (iii) dissemination of research results and concepts to the interested public.
\end{abstract}

IZA Discussion Papers often represent preliminary work and are circulated to encourage discussion. Citation of such a paper should account for its provisional character. A revised version may be available directly from the author. 


\begin{abstract}
The Changing Wage Return to an Undergraduate Education

Between 1990/91 and 2000/01 the number of male undergraduates in Britain increased by over one-third while the number of female undergraduates has increased nearly twofold. Given this substantial increase in supply we would expect some impact on the wage premium for recent graduates unless demand has shifted in parallel. Following Katz and Murphy (1992), we adopt a simple supply and demand framework to analyse changes in earnings mark-ups across degree disciplines over time. Using a propensity score approach to match those graduates entering the labor market with an age balanced sample of individuals with two or more A-Levels from the Labour Force Survey, we find a significant decline in the markup for females, whilst no such change is apparent for males. These aggregate figures, however, mask a great deal of variation across degree subjects, with declines in those subjects in which women predominate and in the lowest quartile of the earnings distribution being identified. The results point to both supply and demand factors impacting on the graduate mark-up as theory would suggest.
\end{abstract}

JEL Classification: $\quad$ I2, J0, J3

Keywords: education, wages

Corresponding author:

Nigel C. O'Leary

WELMERC

Economics Department

James Callaghan Building

University of Wales Swansea

Singleton Park

Swansea SA2 8PP

UK

Email:n.c.oleary@swan.ac.uk 


\section{Introduction}

Between 1990/91 and 2000/01, the number of male undergraduates increased by over a third while the corresponding number of females increased nearly two-fold (Elias and Purcell, 2003). Thus, with ever increasing numbers of workers joining the labour force who have enjoyed a university education, it is natural to ask what is happening to the valuation that the labour marlet places upon such a qualification. Previous research has already highlighted the superior wage outcomes that graduates are afforded (see for example Chevalier and Walker, 2001, Dearden et al., 2002, Harmon and Walker, 2000 and McIntosh, 2004). Against such a backdrop, we would expect that increasing supply would reduce the wage premium paid to graduates ceteris paribus. However, evidence by Walker and Zhu (2003) and Elias and Purcell (2003) has suggested that the rewards to graduates have largely remained constant over this period, which can only be rationalised if there has been an accompanying increase in the demand for graduate workers. More recently, though, Elias and Purcell (2004) have reappraised their earlier conclusions and suggest tentatively that the salaries of recent graduates may have been falling. Likewise, Chevalier et al. (2004) find that returns have fallen for the most recent cohorts in their data-set, a finding which they emphasise was not apparent in the earlier literature. However, they also find that there is no tendency for the downturn to be concentrated at the lower end of the earnings distribution, as one would expect if the less able graduates were concentrated there.

In this paper, we will further this debate by estimating how the premium earned on an undergraduate university education has changed for the stock of graduates in the Labour Force Survey (LFS) over the period between 1993 to 2003. This will be done for men and women separately and at various points along the earnings distribution. We will also focus upon the change in returns by subject of degree, as there is a body of evidence that this has a major impact on the earnings mark-up (see for instance Naylor et al., 2002 and O'Leary and Sloane, 2004). ${ }^{1}$ However, the effect of the government's policy of higher education expansion in the $1990 \mathrm{~s}$ is going to be most keenly felt by recent graduates who are only just emerging onto the labour market. As Elias and Purcell (2004) point out, the true effect is going to be long-term in nature

\footnotetext{
${ }^{1}$ Naylor et al. (2002), as others, also find that class of degree and institution from which it was obtained are significant determinants of the earnings mark-up. Unfortunately, we are unable to control for these factors as the LFS does not have information on them.
} 
and will not be fully realised for a further twenty years or so. This requires one to focus on the experience of the flow of most recent graduates rather than the stock of graduates whose careers and earnings outcomes may be quite immune to recent developments. The importance of demand and supply fators in driving changes in the premiums offered to these recent graduates are also investigated.

The analysis of recent graduates is further extended by examining cohort effects in a similar fashion to Chevalier et al. (2004), who utilised the LFS over the period 1993 to 2001. They divided their sample into four cohorts, separately for men and women, with the youngest cohort being those born between 1969 and 1977 . However, the younger part of this cohort will have graduated before the growth in student numbers had accelerated in the 1990s. We extend the analysis up to the LFS 2003 with the youngest cohort consisting of those born in the 1980s, and thus graduating after a substantial growth in student numbers.

\section{Data}

The data used in this analysis come from the Labour Force Survey (LFS), a largescale survey conducted by the Office for National Statistics (ONS). Switched from an annual to a quarterly basis in 1992, it aims to produce a sample of approximately 60,000 responding households in Great Britain every quarter. Over the course of the survey respondents are interviewed on five separate occasions, commencing in the quarter they enter the survey and then once more in each of the next subsequent four quarters. Following their fifth interview respondents are replaced by a new cohort. This rotating sample design means that within any one quarter approximately onefifth of all respondents are being interviewed for the first time, one-fifth for the second time etc., all the way up to the fifth who are being interviewed for the final time. There is, therefore, an eighty per cent overlap of respondents from any one quarter to the next. To avoid any possible double-counting we ensure that individuals are only picked up once during their participation within the LFS. This is done by selecting respondents only after they have provided earnings information. ${ }^{2}$

\footnotetext{
${ }^{2}$ Between Winter 1992 and Winter 1996, respondents were only asked about their earnings once, and this was during their fifth interview. Since Spring 1997, however, respondents are now asked about their earnings on two separate occasions. These will be during their first (wave 1) and final (wave 5) interviews.
} 
The data used run from the Spring of 1993 to the Winter of 2003. Data availability dictated the starting point and the end point was chosen so as to provide as long a temporal dimension as possible. By pooling the separate quarters and after selecting only those who provided information about their educational level, there were approximately 140,000 males and 146,00 females of working age remaining who had hourly earnings data available. Of these, approximately 15,500 males and 14,200 females had an undergraduate degree as their highest educational qualification.

\section{Methodology}

Consider the following earnings equation estimated over a pooled sample of university graduates $(G)$ and holders of 2 or more A-Levels (A) at the pth percentile of the earnings distribution:

$$
\operatorname{LnY}_{p}=\alpha_{p}+\beta_{p} X+\delta_{p} D+\varepsilon_{p}
$$

where $\mathrm{Y}$ are hourly earnings, $\alpha$ and $\beta$ are coefficient vectors estimated from a quantile regression model, $\mathrm{X}$ is a conformable vector of characteristics that influence earnings, D is a $0-1$ dummy variable that assumes a value of 1 for all university graduates (and 0 otherwise), $\delta$ is the coefficient estimate upon this dummy variable and $\varepsilon$ is a randomly distributed disturbance term. The coefficient $\delta$ will represent the hourly earnings advantage (or premium) that university graduates enjoy over similar workers with a set of characteristics $\mathrm{X}$ but whose highest educational qualification is $2+$ A-Levels. However, a specification such as equation [1] imposes the restriction that the coefficients $\alpha$ and $\beta$ will be the same between groups $G$ and $A$ and the estimate of $\delta$ will therefore be based upon this restriction. Alternatively, estimating separate equations for both groups avoids this restriction upon coefficients:

$$
\begin{aligned}
& \operatorname{LnY_{p}^{G}}=\alpha_{p}^{G}+\beta_{p}^{G} X^{G}+\varepsilon_{p}^{G} \\
& \operatorname{LnY} Y_{p}^{A}=\alpha_{p}^{A}+\beta_{p}^{A} X^{A}+\varepsilon_{p}^{A}
\end{aligned}
$$

where the superscripts $\mathrm{G}$ and $\mathrm{A}$ denote university graduates and 2+ A-Level holders respectively. By making a simple extrapolation from the standard Blinder (1973) and Oaxaca (1973) decomposition framework, the premium (EP) enjoyed by university graduates at any predicted earnings percentile $\mathrm{p}$ can be isolated as follows:

$$
\mathrm{EP}_{\mathrm{p}}=\beta_{\mathrm{p}}^{\mathrm{A}}\left(\overline{\mathrm{X}}^{\mathrm{G}}-\overline{\mathrm{X}}^{\mathrm{A}}\right)
$$


where a bar denotes a mean value. Following Oaxaca and Ransom (1998), standard errors for expression [4] are approximated by:

$$
\left[\beta_{\mathrm{p}}^{\mathrm{A}}\left(\overline{\mathrm{X}}^{\mathrm{G}}-\overline{\mathrm{X}}^{\mathrm{A}}\right)\right]^{2} \overline{\mathrm{X}}^{\mathrm{A} /}\left(\Sigma_{\mathrm{p}}^{\mathrm{G}}+\Sigma_{\mathrm{p}}^{\mathrm{A}}\right) \overline{\mathrm{X}}^{\mathrm{A}}
$$

where $\Sigma$ is the variance-covariance matrix.

To analyse the tendency for the graduate earnings premium to change over time, a simple supply and demand framework is adopted in the spirit of Katz and Murphy (1992). To the extent that graduates in different disciplines are imperfect substitutes for one another, changes in relative earnings can be thought of as being generated by shifts in relative supplies of new graduates and shifts in relative demands for them. At the one extreme, one might hypothesise that changes in relative supplies drive earnings changes; with stable demand this implies that any increase in the supply of graduates in a particular discipline relative to that in others will lead to a reduction in relative earnings for graduates in that discipline. At the other extreme, one might hypothesise that changes in demand, possibly as a result of skill biased technological change, are the driving force. Assuming fixed coefficient manpower requirements, one can measure the percentage change in the demand for a particular type of graduate as the weighted average of the employment for that group, where the weights are given by the employment distribution for that group. Meanwhile, the unemployment rate for that group, reflecting bouyant or tight labour market conditions, can be used as a proxy for demand (again appropriately weighted).

\section{Results}

By way of background to our discussion, point estimates have been calculated for men and women as to the influence of a university degree upon hourly earnings. For each of the survey years in the sample period, a wage equation was estimated using a quantile regressor and a dummy variable included to denote the possession of an undergraduate degree (see equation 1 in the methodology section). This was done at median, lower quartile, and upper quartile earnings and the results of this initial analysis are plotted in Figures 1a-1c respectively. Looking at median earnings first (Figure 1a), there is a striking gender difference and the well-documented superior returns available to women from investing in a university education are clearly evident (see inter alia Walker and Zhu, 2003). Figure 1a also shows strong evidence 
of a fall in the returns to a degree for women. As such, the yearly point estimate for women falls from 0.3855 in 1993 to 0.3038 in 2003, a statistically significant drop in earnings of over 8 percentage points. As might be expected, the point estimates do show some variation across years and merely comparing returns in the two end points cannot be viewed as conclusive proof of a fall in the return to undergraduate degree programmes. Not withstanding this, though, there is undeniably a clear downward trend in the median point estimates for women over the period 1993 to 2003. This is in stark contrast to the profile for men which is much flatter, changing insignificantly (in a statistical sense) from a point estimate of 0.1887 in 1993 to 0.2364 in 2003.

Away from the median, a similar pattern is repeated for men over both the lower (see Figure 1b) and upper quartiles (see Figure 1c) of the earnings distribution. The profile of returns is relatively flat over the course of the decade and there are statistically insignificant differences between point estimates in 1993 and 2003. For women, there is no discernible change over the upper quartile, but the trend over the lower quartile is even more pronounced than has already been discussed at the median. As such, there is an even more visible downward trend in the year by year point estimates and the change between the 1993 and 2003 point estimates is a statistically significant $0.103 \log$ points.

These falling returns for women have occured at a time when the proportion of graduates within the sample has increased dramatically. The top row of Table 1 shows that between the earlier and latter parts of the period, the stock of female graduates has increased by 28.31 per cent. ${ }^{3}$ The comparable increase in the stock of male graduates has been more muted, rising by only 3.13 per cent. While such figures are well below the increases that have been reported in student numbers enrolled upon higher education courses, it should be remembered that these figures reflect the total stock of graduates within the population. If, however, we focus upon only the flow of graduates in these periods rather than the stock, then much more dramatic increases are observed. Thus, the second row of Table 1 looks at only the number of graduates

\footnotetext{
${ }^{3}$ In Table 1 and all reported results that will follow, changes are calculated over the period referred to as 1994-2002. These dates will actually refer to the mid-points of 3 year bands that we use in the analysis in order to boost sample sizes. Thus, 1994 refers to results obtained from pooling LFS surveys from 1993, 1994 and 1995, and likewise 2002 refers to results obtained from pooling surveys over the period 2001 to 2003.
} 
leaving university and entering the labour market within the earlier and later reference period. From here we can see that the number of new graduates in the sample has increased rapidly for both men and women (by $23.22 \%$ and $54.54 \%$ respectively), more in line with nationally reported figures on the change in the student population.

These aggregate figures, though, mask a great deal of variation across degree subjects (see Table 2). For men, the most popular degree courses have typically been in Sciences, Engineering \& Technology and Social Sciences, but between 1994 and 2002 the stock of graduates in these subjects has fallen by $12.01 \%, 12.57 \%$ and $20.60 \%$ respectively. In contrast, subjects in Business \& Finance $(+28.53 \%)$ and Arts $(+27.07 \%)$ have seen a rapid expansion in graduate numbers, in addition to subjects in Other $(+18.85 \%)$ and Maths \& Computing (+8.59\%) disciplines. For women, the most visible growth areas have been Medicine \& Related $(+182.19 \%)$ and Business and Finance (+90.34\%), although Social Sciences $(+32.04 \%)$ and Other subjects $(+28.74 \%)$ have also experienced notable growth. Indeed, it is only Maths \& Computing that has shown a reduction in female graduate numbers, falling by $15.44 \%$ between the earlier and later time periods.

Using the same two time periods as our reference points, the wage premium that is afforded to graduates relative to holders of two or more A-Levels has been calculated. These results, presented in Tables 3 and 4, are disaggregated by broad subject area and are calculated at three points along the earnings distribution: at the lower quartile; at the median; and at the upper quartile. For men (Table 3), large variations across degree schemes are evident, with the highest returns being offered in Maths \& Computing and Medicine \& Related. At the other extreme, Arts subjects consistently offer the lowest returns. There is also evidence that returns diminish as we move to higher moments of the earnings distribution. For example, for all degree subjects aggregated, the calculated premium in 1994 falls from 0.248 at the lower quartile, through 0.208 at the median, to 0.165 at the upper quartile. This fall between the quartiles is statistically significant and is repeated for all but three of the broad subject areas in the earlier time period. For the later period, the evidence is less clear-cut, where only four of the eleven subjects show a statistically significant inter-quartile decline in returns. 
With regard to temporal changes, returns are remarkably stable for most subjects between 1994 and 2002 across the entire earnings distribution. However, Maths \& Computing, Engineering \& Technology, Architecture \& Related and Other subjects all stand out as distinct gainers over the period. At median earnings, Engineering \& Technology (0.1018) has shown the greatest significant increase in rewards, followed by Maths \& Computing (0.0754) and Other (0.0688). At the upper quartile, returns have increased significantly in Architecture \& Related (0.1427), Maths \& Computing (0.1179), Engineering \& Technology (0.0981) and Other subjects (0.0657). The only evidence that can be found for a fall in returns are for Languages and Arts. In the case of Languages, falling premiums have been observed at the lower quartile $(-0.1076)$ and at the median (-0.0569), although this subject area accounts for only one per cent of the graduate stock. A fall of comparable magnitude (-0.0773) is also found at the lower quartile of the earnings distrinution in Arts subjects.

For women (Table 4), the spread of premiums across degree subjects is again pronounced. Some of the highest rewards are in Maths \& Computing and Medicine \& Related, the two subjects found to dominate for men, and there is again evidence to suggest a fall in premiums between the lower and upper quartiles. In the earlier period, the returns to Architecture \& Related, Languages and Education all fall significantly (in a statistical sense) between the lower and upper quartiles. In the later period, significant falls are shown for Medicine \& Related, Maths \& Computing, Architecture \& Related and Languages. ${ }^{4}$

Unlike for men, for whom returns were generally found to be either stable or increasing between 1994 and 2002, the returns for women show clear signs of a decrease. As such, the aggregate figure for all subjects shows significant declines at both the lower quartile (a fall of $0.078 \mathrm{log}$ points) and the median $(0.069 \log$ points). Examining the results for individual subjects, we can see how this aggregate finding is being driven by the observed reductions in just a few key subject areas: in Sciences, there has been a fall in the median estimate of $0.073 \log$ points; in Education, there has been a fall in the median estimate of $0.093 \log$ points; in Arts, the comparable fall

\footnotetext{
${ }^{4}$ In contrast, there is evidence for Engineering \& Technology of an increase in returns across the earnings distribution. In the later period, there is a statistically significant increase in the point estimate of $0.1157 \log$ points between lower and upper quartiles; in the earlier peiod, there is a statistically significant increase of $0.0672 \log$ points between the median and upper quartile.
} 
has been of $0.145 \log$ points. Collectively, these subjects accounted for over 40 per cent of the stock of female graduates in 1994 and over one third of the total stock in 2002. Thus, the finding of falling median returns for women and the earlier impression given in Figure 1 can be traced back to the influence of these three subject areas. It should be remembered, though, that median returns for the majority of subject areas have shown no significant change between 1994 and 2002. However, there is evidence to suggest a more universal fall in returns at the lower quartile. As such, five of the ten subject groupings (accounting for six out of every ten degree holders) show a significant drop in returns between the two time periods.

\section{An Analysis of Recent Graduates - the distinction between stock and flow}

In Table 5, the focus of attention is upon those who have only more recently graduated. By defining such recent graduates as those who had entered the labour market within the previous two years, 327 (359) men (women) are identified in the earlier time period (1993-1995) and 376 (469) in the latter time period (2001-2003). Again, the earnings outcomes of these graduates are compared against comparable employees with two or more A-Levels. However, the age profile of these recent graduates is very young, the vast majority being in their early $20 \mathrm{~s}$, and markedly different from the population possessing A-Levels. To compensate for this, the sample of respondents with 2+ A-Levels has also been adjusted to bring their average age in line with the sample of recent graduates. ${ }^{5}$ Changes over time in earnings premiums received by this group of graduates relative to the subsample of $2+\mathrm{A}$-Level holders are shown in Table $5 .^{6}$

\footnotetext{
${ }^{5}$ The age-balanced sample of non-graduates was constructed using the propensity score approach first discussed by Rosenbaum and Rubin (1983). This produced a sample with a mean age of 23.4 years for both men and women, identical to the samples of recent graduates, and where there was a 1:1 correspondence between graduates and non-graduates. As an alternative estimation strategy, A-level holders of specific ages were randomly selected such that an exact match was achieved between the age distributions of graduates and non-graduates. While this resulted in a somewhat smaller control group (and subsequently higher standard errors upon estimated coefficients), the point estimates reported in Table 5 and the trends suggested by them were closely correlated between the two matching procedures.

${ }^{6}$ The results presented in Table 5 have been generated from pooled samples over the earlier and later time periods with a full set of interactions for all control variables in the estimated wage equations. Baseline returns to a degree are for the earlier time period and the change in returns are captured by an intercept shift from this baseline. These runs also include a control for actual work experience with current employer (entered in quadratic form) which has not been present in the previous analysis.
} 
The top row of the table shows that, for both men and women, recent graduates at the lower quartile of the earnings distribution have seen a fall in the premium afforded to their university education. For men, this fall has been of the order of (a statistically significant) $-0.1011 \log$ points, although the change in returns for any of the individual subject areas fails to achieve statistical significance. For women, the fall has been of $-0.0968 \log$ points and this is again statistically significant at conventional levels of acceptance. The principal drivers of this observed decline are the subject areas of Education (-0.3674), Arts (-0.2276) and Medicine \& Related (-0.2001), which have all seen statistically significant $\log$ point falls. ${ }^{7}$ Outside of the lowest quartile, there is less evidence of a fall in the recent returns, with the aggregate figures showing insignificant changes for both men and women. Notwithstanding this, though, the returns to Medicine \& Related (-0.3760), Sciences (-0.1462) and Other subjects (0.1269 ) show signs of a fall in returns at median earnings. This reinforces the earlier findings from Table 4. Thus, consistent with Chevalier et al (2004), there is clear evidence that recent cohorts of graduates, both male and female, have seen the value attached to their education fall. This is again consistent with recent graduates finding it more difficult to find 'graduate' jobs.

All this is in contrast to the fortunes of male graduates in Maths \& Computing and Engineering \& Technology, who have seen statistically significant and appreciable increases in the premiums their degrees attract at both the median and upper quartile levels. Likewise, a statistically significant increase is also apparent for female graduates in Business \& Finance at median earnings (0.1612). Thus, the picture to be painted is not one of universal decline, but rather one where graduates in some disciplines have prospered at the same time as graduates in others have seen a marked downturn in their fortunes.

\section{The importance of demand and supply factors}

An indication of the effect that relative demand and supply have had in shaping the changing returns for recent graduates, as outlined above, is given in Table 6. Changes in supply are measured as the change in the number of recent graduates in employment as a proportion of the 2002 stock of recent graduates (disaggregated by

\footnotetext{
${ }^{7}$ In contrast, a statistically significant rise of $0.4175 \mathrm{log}$ points is reported in Engineering \& Technology, although this based upon a small number of observations.
} 
subject). Meanwhile, changes in the demand for graduate labour are measured as the change in the number of unemployed recent graduates within a particular discipline relative to the 2002 stock of recent of graduates (again disaggregated by subject). The changes in these two measures between 2002 and 1994 are then regressed upon changes in the wage premium by subject (with estimates being weighted by 2002 employment shares). ${ }^{8}$

The importance of demand and supply factors is emphasised. With the exception of the estimates for women at the upper quartile level, changes in demand and supply have been working in the direction that we would have expected them to a priori. There is also evidence to suggest that supply changes have been the dominant factor in driving the observed changes in degree premiums. Thus, the magnitude of the effect of supply is statistically greater than the magnitude of the effect of demand for both men and women over all the ranges presented in Table 6 with the exception of the aforementioned upper quartile for women.

Such a body of evidence would provide support for two opposing schools of thought. On the one hand there is the view - a view that underpins current policy on higher education - that the demand for graduate skill is increasing and that the current expansion of higher education is needed to meet this increase. On the evidence of Table 6, there is clearly support for this particular hypothesis. Over the period 19942002, the incidence of graduate unemployment has fallen in all of the broad subjects areas that we examine. If we take this to be indicative of an increasing demand for the skills that graduates possess, it suggests an increase in the demand for graduate labour over the same period and this has been shown to have had a positive and significant causal effect upon degree premiums.

The opposing school of thought would suggest that increases in the supply of graduates would cause a depreciation of the value attached to degree-holding in the labour market. Again there is support for this particular hypothesis. Tables 1 and 2 have previously identified the recent expansion of graduate numbers and such an expansion has be shown to have had a significant and negative effect upon degree

\footnotetext{
${ }^{8}$ To control for potential heteroskedasticity, all estimates have been deflated by the standard errors on the estimated changes in returns to degrees.
} 
premiums. However, the evidence that can be drawn from Tables 5 and 6 would suggest that recent declines in the rewards to certain degree disciplines, primarily focussed towards the lower end of the earnings distribution, have been driven by the increased flow of graduates on to the labour market, in spite of the more buoyant labour market conditions that have been enjoyed in the UK over the period

\section{An Analysis by Cohort}

Supporting evidence to the above conclusion can also be found in Table 7, where the degree premiums afforded to various birth cohorts are presented. For earlier birth cohorts of men, the returns to a degree have remained relatively stable at all point across the earnings distribution and returns for the 1970s cohort are near identical to those estimated for the 1940s cohort. However, there has been some fluctuation in the reported point estimates between these dates. For example, median estimates show that returns fell by $-0.0385 \log$ points between the $1950 \mathrm{~s}$ and $1960 \mathrm{~s}$ cohorts and rose by $0.0593 \log$ points between the 1960s and 1970s. An even more dramatic change is seen between the 1970s and 1980s cohorts, where the estimated median degree return for men has fallen from 0.2314 to 0.1417 , a fall of $-0.0897 \log$ points. ${ }^{9}$ Even more striking is the magnitude of the drop over the lower quartile, estimated at a statistically significant $-0.1293 \log$ points. This figure, though, might be slightly misleading, as those graduates who were born during the 1980s will still be very early in their careers and will have accumulated relatively little work experience in comparison to the cohort of $2+$ A-level holders. As specific controls for work experience have not been included in the wage equations (seniority and experience are proxied by age), the estimated returns to degrees for such a young cohort will be biased downwards. For this reason, the returns for the 1970s and 1980s cohorts have been re-estimated with controls for time with current employer included within the wage equations. The results of this exercise are shown in Table $7 \mathrm{a}$.

For men, the effect of controlling for tenure with current employer upon estimated degree premiums for the 1970 s cohort is negligible. For example, the median point estimate changes from 0.2325 (Table 7) to 0.2431 (Table 7a), and a similar pattern is repeated for the upper and lower quartile points. In contrast, the effect upon the

\footnotetext{
${ }^{9}$ Although larger in magnitude than the changes reported over earlier decades, this figure is not statistically significant. The large standard errors on the 1980s estimates would explain this.
} 
younger 1980s cohort is pronounced, with the median (lower quartile/upper quartile) point estimate increasing from $0.1417(0.0962 / 0.0913)$ to $0.2034(0.1455 / 0.1868)$. The effect of these recalculations is to reduce the magnitude of the decline that has taken place in the degree premium between the 1970s and 1980s cohorts. The greatest decline (-0.0816) is still demonstrated over the lower quartile of earners, but neither this nor the reported declines over the other parts of the earnings distribution are statistically significant at conventional levels of acceptance.

Meanwhile, there is evidence of a decline in returns for women from the 1960s and onwards (Table 7). For example, while returns appear stable over the 1940s and 1950s cohorts, there is a fall in the median estimate of -0.0774 between the cohorts of the 1950s and the 1960s. The comparison over the next decade shows an even larger decline of -0.1341 . Both of these falls are statistically significant. A similar trend is repeated over the lower quartile, where estimated premiums have fallen by -0.0870 between the 1950s and 1960s cohorts and by -0.1042 between the 1960 s and 1970 s cohorts. When focussing upon the most recent cohort and controlling for tenure with current employer (Table 7a), there is again evidence that there has been a decline in degree returns. However, it is only over the lower quartile $(-0.1229)$ that the fall between the 1970 s and 1980 s birth cohorts is statistically significant. ${ }^{10}$

\section{Conclusions}

The rapid expansion of the higher education system that has been witnessed in the UK has not led to a wholesale decline in the fortunes of recent graduates and the value placed upon their degrees in the labour market. Indeed, subjects in the Maths \& Computing and Engineering \& Technology spheres have fared well, and for a number of subjects there has been little identifiable change over the period under examination. However, there is concerted evidence to suggest that the expansion in student numbers has led to some moderation of the financial rewards offered to recent cohorts of graduates. These findings are more pronounced for women than they are for men,

\footnotetext{
${ }^{10}$ These findings for men and women are consistent with the results presented by Chevalier et al. (2004), who found that returns to a degree have decreased substantially across all quartiles for the most recent cohort in their analysis. Their results, though, had 1977 as the latest birth year, while our own results would show that this downward trend has been continued for more recent birth cohorts. Likewise, Bratti, Naylor and Smith (2005) found that the return to a first degree for women has declined rapidly between birth cohorts in 1958 and 1970, although the returns to men changed little.
} 
are more pronounced in the lower reaches of the skill/earnings distribution than at higher skill/earnings levels, and are more concentrated for Arts degrees than for other degree subjects. While it is also true that the demand for graduate skill has also been increasing over the same time period, it does not appear to have compensated for the supply changes. In part, these results are consistent with a decline in the quality of graduates as a consequence of expansion.

The policy implications are complex. Student fees might be set differentially across disciplines, with higher fees set where demand and supply conditions are more favourable as students in these areas will have a greater ability to pay following graduation. However, one might argue quite the reverse, if it is believed that lower fees will attract more students and this is more likely to match demand and supply i.e. the supply side will dominate and rewards currently enjoyed will be bid down. All of this presupposes that students do not themselves rapidly adjust to supply and demand, either through imperfect knowledge or because they value the consumption prospect of education. 


\section{References}

Blinder A. (1973) "Wage Discrimination: Reduced Form and Structural Estimates", Journal of Human Resources, 8, pp. 436-455.

Bratti M., Naylor R. and Smith J. (2005) "Variations in the Wage Returns to a First Degree: Evidence from the British Cohort Study 1970, mimeo, University of Warwick.

Chevalier A., Harmon C., Walker I. and Zhu Y. (2004) "Does Education Raise Productivity, or Just Reflect it?", Economic Journal, 114, pp. F499-F517.

Chevalier A. and Walker I. (2001) "The United Kingdom", in Harmon C., Walker I. and Westergaard-Nielsen N. (eds) Education and Earnings in Europe: A Cross Country Analysis of the Returns to Education, Edward Elgar: Cheltenham.

Dearden L., McIntosh S., Myck M. and Vignoles A. (2002) "The Returns to Academic and Vocational Qualifications in Britain", Bulletin of Economic Research, 54, pp. 249-274.

Elias P. and Purcell K. (2003) "Measuring Change in the Graduate Labour Market", Research Report No. 1, IER/ESRU.

Elias P. and Purcell K. (2004) "The Earnings of Graduates in their Early Careers", Research Report No. 5, IER/ESRU.

Harmon C. and Walker I. (2000) "Returns to the Quantity and Quality of Education: Evidence for Men in England and Wales", Economica, 67, pp. 19-35.

Katz L. and Murphy K. (1992) "Changes in Relative Wages, 1963-1987: Supply and Demand Factors", Quarterly Journal of Economics, 107, pp. 35-78.

McIntosh S. (2004) "Further Analysis of the Returns to Academic and Vocational Qualifications", Department for Education and Skills, Research Report No. 370, HMSO: Norwich.

Naylor R., Smith J. and McKnight A. (2002) "Why is there a Graduate Earnings Premiumfor Students from Independent Schools?", Bulletin of Economic Research, 54, pp. 315-339.

Oaxaca R. (1973) "Male-Female Wage Differentials in Urban Labour Markets", International Economic Review, 14, pp. 693-709.

Oaxaca R. and Ransom M. (1998) "Calculation of Approximate Variances for Wage Decomposition Differentials", Journal of Economic and Social Measurement, 24, pp. 55-61.

O'Leary N. and Sloane P. (2004) "The Return to a University Education in Great Britain", mimeo, University of Wales Swansea.

Rosenbaum P. and Ruben D. (1983) "The Central Role of the Propensity Score in Observational Studies for Causal Effects", Biometrika, 70, pp. 41-55. 
Walker I. and Zhu Y. (2003) "Education, Earnings and Productivity: Recent UK Evidence", Labour Market Trends, March, pp. 145-152. 
Figure 1a

Median Degree Markups by Gender Relative to

2+ A-Levels

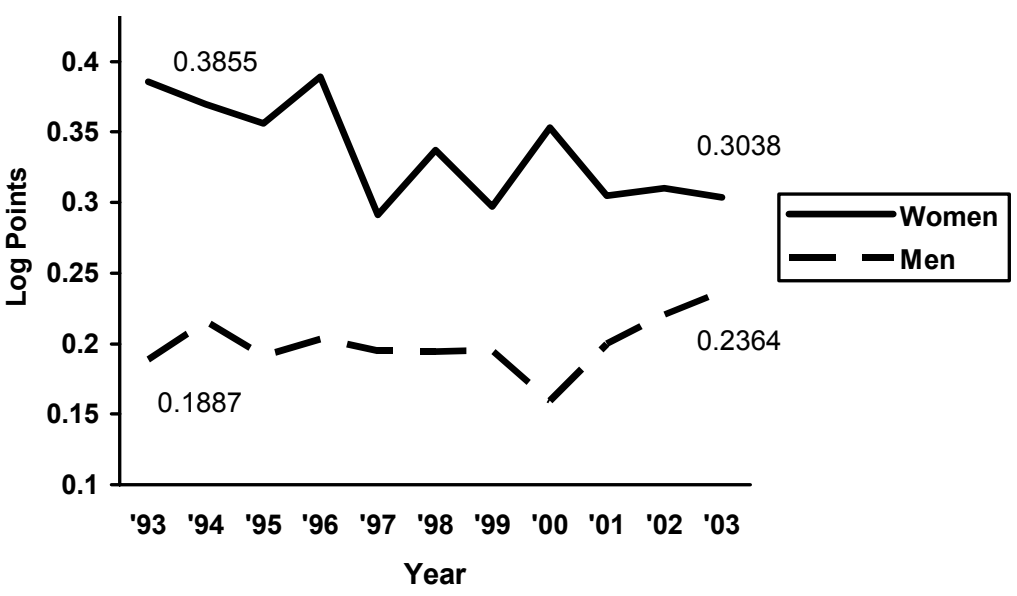

Figure 1b

Lower Quartile Degree Markups by Gender Relative to 2+ A-Levels

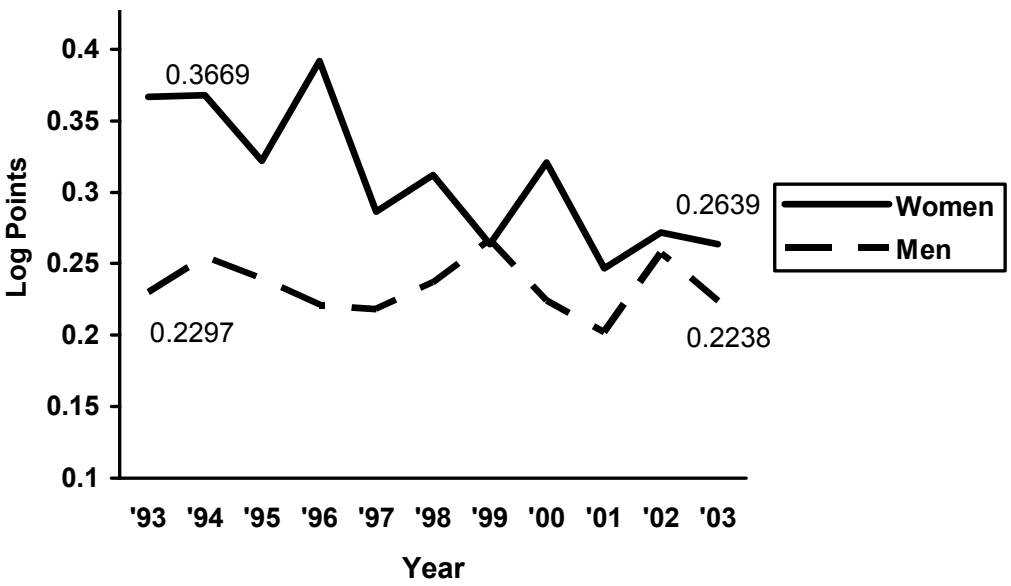

Figure 1c

Upper Quartile Degree Markups by Gender Relative to 2+ A-Levels

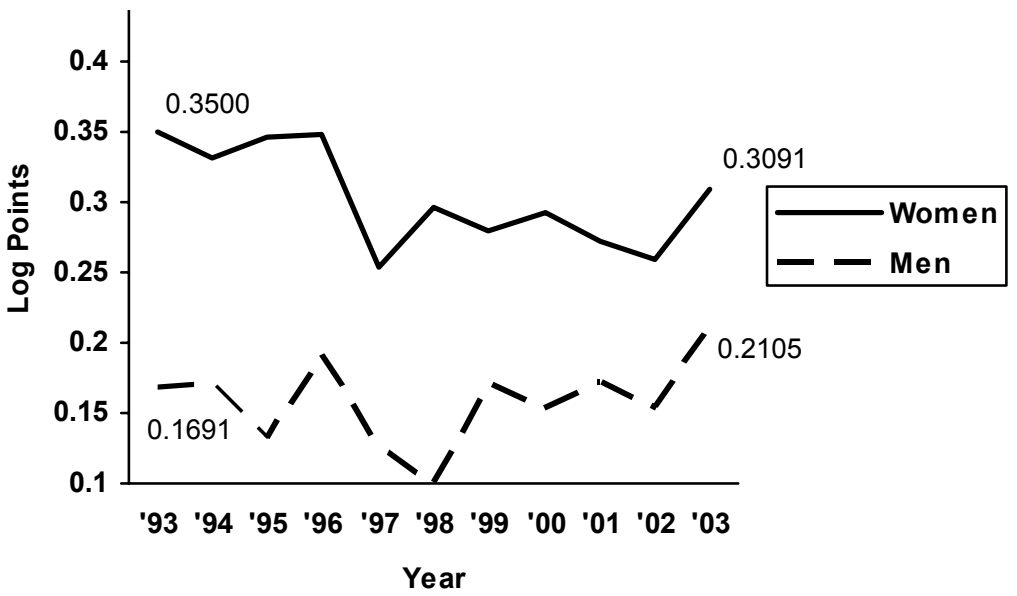


Table 1

Stock of Graduates: LFS 1993Q1-2003Q4

\begin{tabular}{|c|c|c|c|c|c|c|}
\hline & \multicolumn{3}{|c|}{ Men } & \multicolumn{3}{|c|}{ Women } \\
\hline & 1994 & 2002 & $\% \Delta 494-02$ & 1994 & 2002 & $\% \Delta 494-02$ \\
\hline All graduates & 4339 & 4475 & +3.13 & 3483 & 4469 & +28.31 \\
\hline New graduates & 193 & 238 & +23.22 & 198 & 304 & +53.54 \\
\hline
\end{tabular}

Notes: new graduates are classifed as having started work within the previous year; 1994 (2002) denotes the three year period 1993-1995 (2001-2003). 
Table 2

Breakdown of Graduate Stock by Degree Subject: LFS 1993Q1-2003Q4

\begin{tabular}{|c|c|c|c|c|c|c|}
\hline & \multicolumn{3}{|c|}{ Men } & \multicolumn{3}{|c|}{ Women } \\
\hline & $\begin{array}{l}1994 \\
(\%)\end{array}$ & $\begin{array}{l}2002 \\
(\%)\end{array}$ & $\begin{array}{c}\Delta 94-02 \\
(\%)\end{array}$ & $\begin{array}{l}1994 \\
(\%)\end{array}$ & $\begin{array}{l}2002 \\
(\%)\end{array}$ & $\begin{array}{c}\Delta 94-02 \\
(\%)\end{array}$ \\
\hline Medicine \& related & 2.67 & 2.66 & +2.59 & 4.19 & 9.22 & +182.19 \\
\hline Sciences & 14.77 & 12.60 & -12.01 & 12.00 & 9.38 & +0.24 \\
\hline Maths \& computing & 7.51 & 7.91 & +8.59 & 4.28 & 2.82 & -15.44 \\
\hline Engineering \& technology & 19.24 & 16.31 & -12.57 & 1.26 & 1.43 & +45.45 \\
\hline Architecture \& related & 2.47 & 3.46 & +44.86 & 0.57 & 0.56 & +25.00 \\
\hline Social sciences & 12.31 & 9.47 & -20.60 & 12.55 & 12.91 & +32.04 \\
\hline Business \& finance & 7.35 & 9.16 & +28.53 & 5.94 & 8.82 & +90.34 \\
\hline Arts & 9.20 & 11.33 & +27.07 & 17.92 & 16.22 & +16.19 \\
\hline Languages & 0.97 & 1.03 & +9.52 & 2.67 & 2.24 & +7.53 \\
\hline Education & 4.31 & 3.93 & -5.88 & 11.94 & 9.64 & +3.61 \\
\hline Other & 19.20 & 22.12 & +18.85 & 26.67 & 26.76 & +28.74 \\
\hline
\end{tabular}

Notes: 1994 (2002) denotes the three year period 1993-1995 (2001-2003). 
Table 3

Mid-Year Degree Markups for Men Relative to 2+ A-Levels by Quantile: LFS 1993Q1-2003Q4

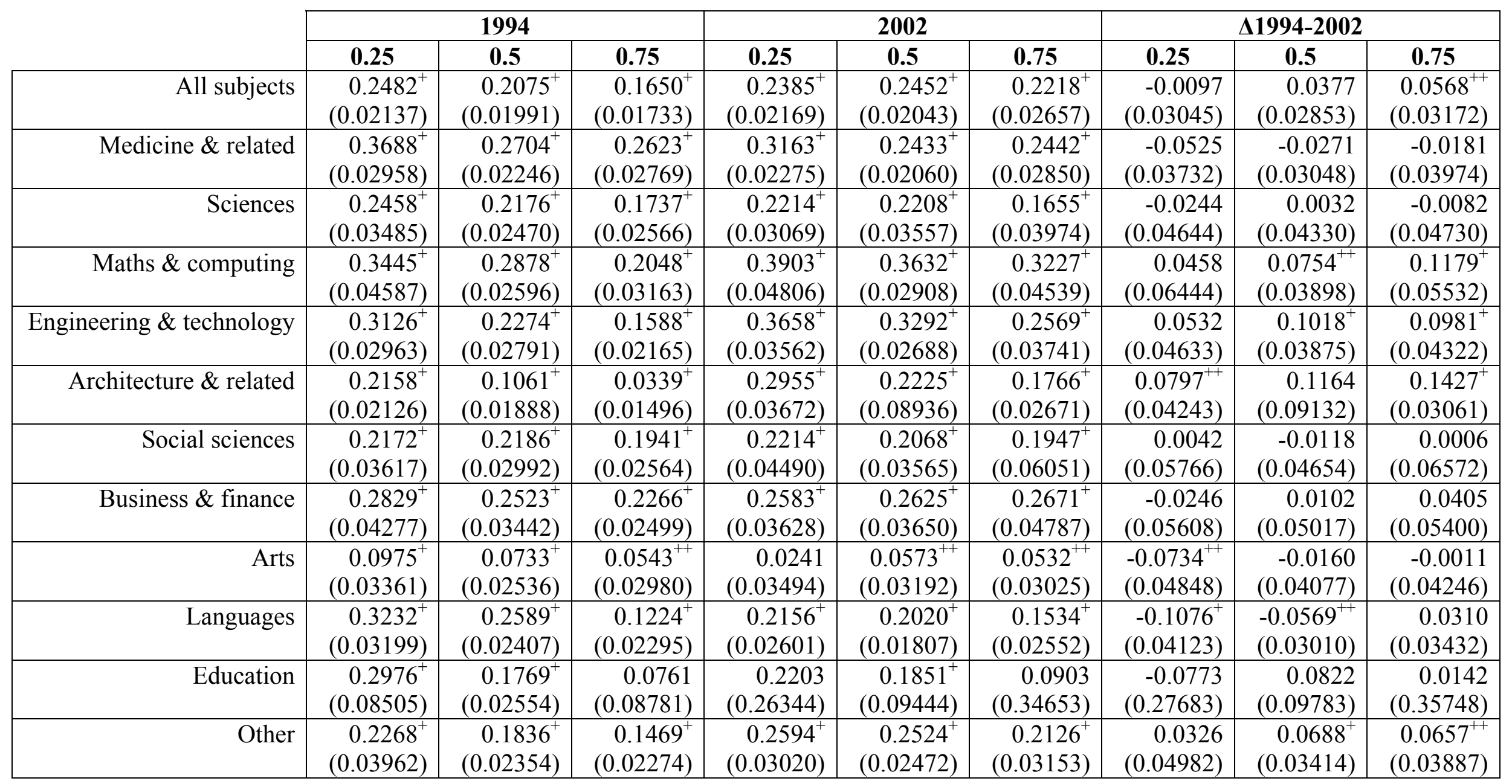

Notes: standard errors in parenthesis;

${ }^{+}\left({ }^{++}\right)$denotes statistical significance at the $95 \%(90 \%)$ confidence level. 
Table 4

Mid-Year Degree Markups for Women Relative to 2+ A-Levels by Quantile: LFS 1993Q1-2003Q4

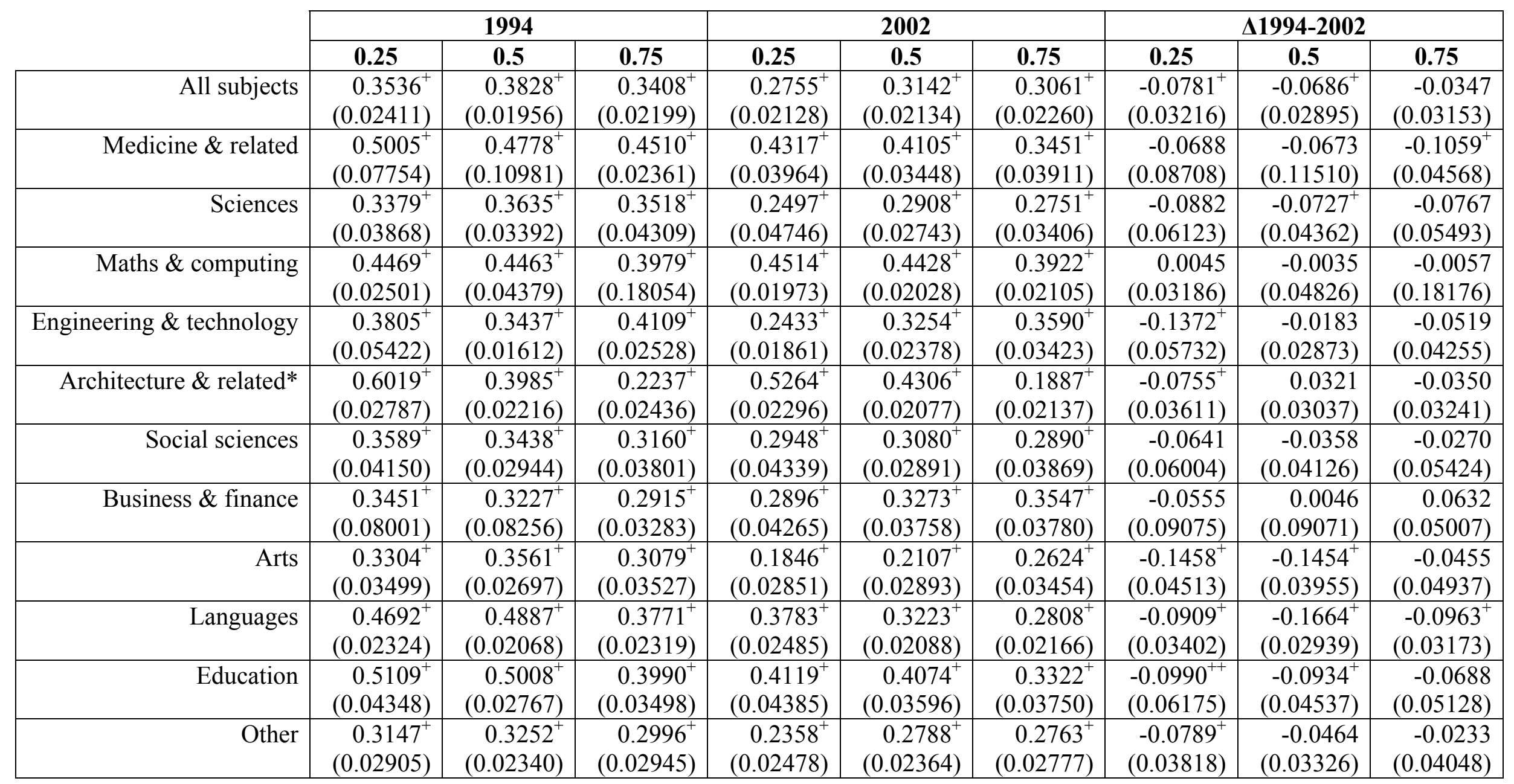

Notes: standard errors in parenthesis;

${ }^{+}\left({ }^{++}\right)$denotes statistical significance at the $95 \%(90 \%)$ confidence level;

* denotes that results are for 1993-1996 and 2000-2003. 
Table 5

Mid-Year Degree Markups for Recent Graduates Relative to 2+ A-Levels:

LFS 1993Q1-2003Q4

\begin{tabular}{|c|c|c|c|c|c|c|}
\hline & \multicolumn{3}{|c|}{ Men $\triangle 194-02$} & \multicolumn{3}{|c|}{ Women $\Delta$ 94-02 } \\
\hline & 0.25 & 0.5 & 0.75 & 0.25 & 0.5 & 0.75 \\
\hline All subjects & $\begin{array}{r}-0.1011^{+} \\
(700)\end{array}$ & $\begin{array}{r}-0.0511 \\
(700)\end{array}$ & $\begin{array}{r}0.0538 \\
(700)\end{array}$ & $\begin{array}{r}-0.0968^{+} \\
(828)\end{array}$ & $\begin{array}{r}0.0069 \\
(828)\end{array}$ & $\begin{array}{r}0.0499 \\
(828)\end{array}$ \\
\hline Medicine \& related & $\begin{array}{r}-0.2510 \\
(23) \\
\end{array}$ & $\begin{array}{r}-0.3760^{+} \\
(23) \\
\end{array}$ & $\begin{array}{r}-0.2076 \\
(23) \\
\end{array}$ & $\begin{array}{r}-0.2001^{++} \\
(62)\end{array}$ & $\begin{array}{r}0.0932 \\
(62) \\
\end{array}$ & $\begin{array}{r}0.0348 \\
(62)\end{array}$ \\
\hline Sciences & $\begin{array}{r}-0.0643 \\
(80)\end{array}$ & $\begin{array}{r}-0.1462^{++} \\
(80)\end{array}$ & $\begin{array}{r}-0.1191 \\
(80)\end{array}$ & $\begin{array}{r}0.0457 \\
(108)\end{array}$ & $\begin{array}{r}0.0119 \\
(108)\end{array}$ & $\begin{array}{r}0.0048 \\
(108)\end{array}$ \\
\hline Maths \& computing & $\begin{array}{r}0.0344 \\
(70)\end{array}$ & $\begin{array}{r}0.1767^{++} \\
(70)\end{array}$ & $\begin{array}{r}0.2828^{+} \\
(70)\end{array}$ & $\begin{array}{r}0.1193 \\
(23)\end{array}$ & $\begin{array}{r}0.1700 \\
(23)\end{array}$ & $\begin{array}{r}0.0056 \\
(23)\end{array}$ \\
\hline Engineering \& technology & $\begin{array}{r}0.0769 \\
(77) \\
\end{array}$ & $\begin{array}{r}0.2085^{+} \\
\text {(77) }\end{array}$ & $\begin{array}{r}0.2756^{+} \\
(77)\end{array}$ & $\begin{array}{r}0.4175^{++} \\
(10)\end{array}$ & $\begin{array}{r}0.2002 \\
(10)\end{array}$ & $\begin{array}{r}-0.1801 \\
(10)\end{array}$ \\
\hline Architecture \& related & $\begin{array}{r}-0.2065 \\
(29) \\
\end{array}$ & $\begin{array}{r}0.0501 \\
(29) \\
\end{array}$ & $\begin{array}{r}0.0896 \\
(29) \\
\end{array}$ & $\begin{array}{r}-0.0203 \\
(7) \\
\end{array}$ & $\begin{array}{r}-0.1687 \\
(7) \\
\end{array}$ & $\begin{array}{r}-0.1396 \\
(7) \\
\end{array}$ \\
\hline Social sciences & $\begin{array}{r}0.1649 \\
(88) \\
\end{array}$ & $\begin{array}{r}0.0507 \\
(88) \\
\end{array}$ & $\begin{array}{r}-0.0202 \\
(88) \\
\end{array}$ & $\begin{array}{r}-0.0286 \\
(112) \\
\end{array}$ & $\begin{array}{r}0.0327 \\
(112) \\
\end{array}$ & $\begin{array}{r}-0.0248 \\
(112) \\
\end{array}$ \\
\hline Business \& finance & $\begin{array}{r}0.0350 \\
(88) \\
\end{array}$ & $\begin{array}{r}0.0235 \\
(88) \\
\end{array}$ & $\begin{array}{r}0.0857 \\
(88) \\
\end{array}$ & $\begin{array}{r}0.1139 \\
(85) \\
\end{array}$ & $\begin{array}{r}0.1612^{+} \\
(85) \\
\end{array}$ & $\begin{array}{r}0.1202 \\
(85) \\
\end{array}$ \\
\hline Arts & $\begin{array}{r}-0.0697 \\
(79)\end{array}$ & $\begin{array}{r}-0.0612 \\
(79)\end{array}$ & $\begin{array}{r}-0.0178 \\
(79)\end{array}$ & $\begin{array}{r}-0.2266^{+} \\
(134)\end{array}$ & $\begin{array}{r}-0.0785 \\
(134)\end{array}$ & $\begin{array}{r}-0.0847 \\
(134)\end{array}$ \\
\hline Languages & $\begin{array}{r}0.1576 \\
(8) \\
\end{array}$ & $\begin{array}{r}-0.0209 \\
(8) \\
\end{array}$ & $\begin{array}{r}0.0609 \\
(8) \\
\end{array}$ & $\begin{array}{r}-0.1568 \\
(12) \\
\end{array}$ & $\begin{array}{r}-0.0869 \\
(12) \\
\end{array}$ & $\begin{array}{r}0.1931 \\
(12) \\
\end{array}$ \\
\hline Education & $\begin{array}{r}-0.1471 \\
(15) \\
\end{array}$ & $\begin{array}{r}0.0103 \\
(15) \\
\end{array}$ & $\begin{array}{r}0.2049 \\
(15) \\
\end{array}$ & $\begin{array}{r}-0.3674^{+} \\
(52) \\
\end{array}$ & $\begin{array}{r}-0.0695 \\
(52) \\
\end{array}$ & $\begin{array}{r}-0.2079 \\
(52) \\
\end{array}$ \\
\hline Other & $\begin{array}{r}-0.1027 \\
(143)\end{array}$ & $\begin{array}{r}-0.1269^{++} \\
(143)\end{array}$ & $\begin{array}{r}0.0084 \\
(143)\end{array}$ & $\begin{array}{r}-0.0524 \\
(223)\end{array}$ & $\begin{array}{r}0.0257 \\
(223)\end{array}$ & $\begin{array}{r}0.0506 \\
(223)\end{array}$ \\
\hline Sample size & & 1376 & & & 1635 & \\
\hline
\end{tabular}

Notes: number of graduates in sample in parenthesis;

${ }^{+}\left({ }^{++}\right)$denotes statistical significance at the $95 \%$ (90\%) confidence level; recent graduates are classified as those graduates who started work within the previous to years;

estimates derived from a pooled equation with a full set of interaction terms; tenure with current employer (months) included as a control. 
Table 6

Changes in Degree Premiums and Relative Supply/Demand of Recent Graduates: 1994-2002

\begin{tabular}{|c|c|c|c|c|c|c|c|c|}
\hline \multirow[b]{3}{*}{ Quartile } & \multicolumn{4}{|c|}{ Males } & \multicolumn{4}{|c|}{ Females } \\
\hline & \multicolumn{2}{|c|}{$\Delta$ Supply } & \multicolumn{2}{|c|}{$\Delta$ Demand } & \multicolumn{2}{|c|}{$\Delta$ Supply } & \multicolumn{2}{|c|}{$\Delta$ Demand } \\
\hline & coef & t-stat & coef & t-stat & coef & $t$-stat & coef & t-stat \\
\hline 0.25 & -0.344 & -16.12 & 0.149 & 10.09 & -0.251 & -6.66 & 0.120 & 6.20 \\
\hline 0.5 & -0.431 & -14.03 & 0.222 & 10.38 & -0.168 & -8.27 & 0.069 & 6.51 \\
\hline 0.75 & -0.223 & -6.21 & 0.056 & 2.14 & -0.015 & -0.60 & -0.030 & -2.36 \\
\hline
\end{tabular}


Table 7

Degrees Markup by Quartile Relative to 2+ A-Levels by Birth Cohort: LFS 1993Q1-2003Q4

\begin{tabular}{|r|r|r|r|r|r|r|}
\cline { 2 - 7 } \multicolumn{1}{c|}{} & \multicolumn{3}{|c|}{ Males } & \multicolumn{1}{c|}{ Females } \\
\cline { 2 - 7 } \multicolumn{1}{c|}{} & \multicolumn{1}{c|}{$\mathbf{0 . 2 5}$} & \multicolumn{1}{c|}{$\mathbf{0 . 5}$} & \multicolumn{1}{c|}{$\mathbf{0 . 7 5}$} & \multicolumn{1}{c|}{$\mathbf{0 . 2 5}$} & \multicolumn{1}{c|}{$\mathbf{0 . 5}$} & \multicolumn{1}{c|}{$\mathbf{0 . 7 5}$} \\
\hline $1940 \mathrm{~s}$ & $0.2236^{+}$ & $0.2325^{+}$ & $0.1556^{+}$ & $0.3913^{+}$ & $0.4453^{+}$ & $0.4291^{+}$ \\
& $(0.03592)$ & $(0.02612)$ & $(0.02795)$ & $(0.03978)$ & $(0.02988)$ & $(0.04138)$ \\
\hline $1950 \mathrm{~s}$ & $0.2461^{+}$ & $0.2106^{+}$ & $0.1751^{+}$ & $0.4021^{+}$ & $0.4287^{+}$ & $0.3839^{+}$ \\
& $(0.02059)$ & $(0.01647)$ & $(0.01611)$ & $(0.02902)$ & $(0.02754)$ & $(0.03007)$ \\
\hline $1960 \mathrm{~s}$ & $0.2018^{+}$ & $0.1721^{+}$ & $0.1511^{+}$ & $0.3151^{+}$ & $0.3513^{+}$ & $0.3303^{+}$ \\
& $(0.02101)$ & $(0.01834)$ & $(0.01786)$ & $(0.01998)$ & $(0.01716)$ & $(0.02012)$ \\
\hline $1970 \mathrm{~s}$ & $0.2255^{+}$ & $0.2314^{+}$ & $0.1662^{+}$ & $0.2109^{+}$ & $0.2172^{+}$ & $0.2272^{+}$ \\
& $(0.02043)$ & $(0.02430)$ & $(0.02231)$ & $(0.01752)$ & $(0.01982)$ & $(0.01903)$ \\
\hline $1980 \mathrm{~s}$ & $0.0962^{++}$ & $0.1417^{+}$ & 0.0913 & 0.0324 & $0.0869^{++}$ & $0.0835^{++}$ \\
& $(0.05955)$ & $(0.06117)$ & $(0.06571)$ & $(0.05406)$ & $(0.05540)$ & $(0.04778)$ \\
\hline$\Delta 40 \mathrm{~s}-50 \mathrm{~s}$ & 0.0225 & -0.0219 & 0.0195 & 0.0108 & -0.0166 & -0.0452 \\
\hline$\Delta 50 \mathrm{~s}-60 \mathrm{~s}$ & $-0.0443^{++}$ & $-0.0385^{++}$ & -0.0240 & $-0.0870^{+}$ & $-0.0774^{+}$ & -0.0536 \\
\hline$\Delta 60 \mathrm{~s}-70 \mathrm{~s}$ & 0.0237 & $0.0593^{++}$ & 0.0151 & $-0.1042^{+}$ & $-0.1341^{+}$ & $-0.1031^{+}$ \\
\hline$\Delta 70 \mathrm{~s}-80 \mathrm{~s}$ & $-0.1293^{+}$ & -0.0897 & -0.0749 & $-0.1785^{+}$ & $-0.1303^{+}$ & $-0.1437^{+}$ \\
\hline
\end{tabular}

Notes: standard errors in parenthesis;

${ }^{+}\left(^{++}\right)$denotes statistical significance at the $95 \%$ (90\%) confidence level. 
Table 7a

Degrees Markup by Quartile Relative to 2+ A-Levels by Birth Cohort: LFS 1993Q1-2003Q4

\begin{tabular}{|l|r|r|r|r|r|r|}
\cline { 2 - 7 } \multicolumn{1}{c|}{} & \multicolumn{3}{c|}{ Males } & \multicolumn{1}{c|}{ Females } \\
\cline { 2 - 7 } \multicolumn{1}{c|}{} & $\mathbf{0 . 2 5}$ & $\mathbf{0 . 5}$ & $\mathbf{0 . 7 5}$ & $\mathbf{0 . 2 5}$ & \multicolumn{1}{c|}{$\mathbf{0 . 5}$} & \multicolumn{1}{c|}{$\mathbf{0 . 7 5}$} \\
\hline $1970 \mathrm{~s}$ & $0.2271^{+}$ & $0.2431^{+}$ & $0.1601^{+}$ & $0.2182^{+}$ & $0.2276^{+}$ & $0.2225^{+}$ \\
& $(0.01785)$ & $(0.02552)$ & $(0.02530)$ & $(0.02292)$ & $(0.02312)$ & $(0.02139)$ \\
\hline $1980 \mathrm{~s}$ & $0.1455^{++}$ & $0.2034^{++}$ & $0.1868^{+}$ & $0.0953^{+}$ & $0.1446^{+}$ & $0.1350^{+}$ \\
& $(0.08805)$ & $(0.12458)$ & $(0.08877)$ & $(0.04247)$ & $(0.05438)$ & $(0.05526)$ \\
\hline$\Delta 70 \mathrm{~s}-80 \mathrm{~s}$ & -0.0816 & -0.0397 & 0.0267 & $-0.1229^{+}$ & -0.0830 & -0.0875 \\
\hline
\end{tabular}

Notes: standard errors in parenthesis;

${ }^{+}\left({ }^{++}\right)$denotes statistical significance at the 95\% (90\%) confidence level; tenure with current employer (months entered as quadratic) included as control. 